Old Dominion University

ODU Digital Commons

$11-2020$

\title{
Modulation of ROS in Nanosecond-Pulsed Plasma-Activated Media for Dosage-Dependent Cancer Cell Inactivation in vitro
}

\author{
Chunqi Jiang \\ Old Dominion University, cjiang@odu.edu \\ Esin Bengisu Sozer \\ Old Dominion University, esozer@odu.edu \\ Shutong Song \\ Old Dominion University, ssong003@odu.edu \\ Nicola Lai \\ Old Dominion University, nlai@odu.edu \\ P. Thomas Vernier \\ Old Dominion University, pvernier@odu.edu
}

See next page for additional authors

Follow this and additional works at: https://digitalcommons.odu.edu/bioelectrics_pubs

Part of the Biomedical Engineering and Bioengineering Commons, Cell Biology Commons, Medical Biotechnology Commons, and the Oncology Commons

\section{Original Publication Citation}

Jiang, C., Sözer, E. B., Song, S., Lai, N., Vernier, P. T., \& Guo, S. (2020). Modulation of ROS in nanosecondpulsed plasma-activated media for dosage-dependent cancer cell inactivation in vitro. Physics of Plasmas, 27(11), 1-9, Article 113513. https://doi.org/10.1063/5.0020435

This Article is brought to you for free and open access by the Frank Reidy Research Center for Bioelectrics at ODU Digital Commons. It has been accepted for inclusion in Bioelectrics Publications by an authorized administrator of ODU Digital Commons. For more information, please contact digitalcommons@odu.edu. 


\section{Authors}

Chunqi Jiang, Esin Bengisu Sozer, Shutong Song, Nicola Lai, P. Thomas Vernier, and Sigi Guo 


\section{Modulation of ROS in nanosecond-pulsed plasma-activated media for dosage- dependent cancer cell inactivation in vitro}

SCI

Cite as: Phys. Plasmas 27, 113513 (2020); https://doi.org/10.1063/5.0020435

Submitted: 01 July 2020 . Accepted: 21 October 2020 . Published Online: 20 November 2020

C. Jiang, E. B. Sözer, S. Song, N. Lai, P. T. Vernier, and S. Guo

\section{COLLECTIONS}

F This paper was selected as Featured

SCI This paper was selected as Scilight
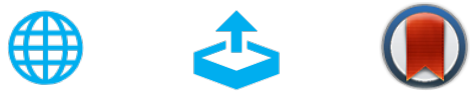

\section{ARTICLES YOU MAY BE INTERESTED IN}

Physics of E×B discharges relevant to plasma propulsion and similar technologies

Physics of Plasmas 27, 120601 (2020); https://doi.org/10.1063/5.0010135

Transient magnetic field diffusion considerations relevant to magnetically assisted indirect drive inertial confinement fusion

Physics of Plasmas 27, 112711 (2020); https://doi.org/10.1063/5.0022722

Investigating use of reactive oxygen species using cold plasma for cancer therapy

Scilight 2020, 471109 (2020); https://doi.org/10.1063/10.0002832

\section{AlP Advances Fluids and Plasmas Collection}




\title{
Modulation of ROS in nanosecond-pulsed plasma-activated media for dosage-dependent cancer cell inactivation in vitro $\odot$ (3)
}

Cite as: Phys. Plasmas 27, 113513 (2020); doi: 10.1063/5.0020435

Submitted: 1 July 2020 - Accepted: 21 October 2020 .

Published Online: 20 November 2020

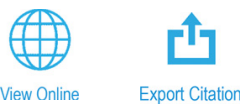

C. Jiang, ${ }^{1,2, a)}$ (D) E. B. Sözer, ${ }^{1}$ S. Song, ${ }^{1,2}$ N. Lai, ${ }^{2,3}$ P. T. Vernier, ${ }^{1}$ and S. Guo ${ }^{1}$

\author{
AFFILIATIONS \\ ${ }^{7}$ Frank Reidy Research Center for Bioelectrics, Old Dominion University, Norfolk, Virginia 23508, USA \\ ${ }^{2}$ Department of Electrical and Computer Engineering, Old Dominion University, Norfolk, Virginia 23529, USA \\ ${ }^{3}$ Department of Mechanical, Chemical, and Materials Engineering, University of Cagliari, Cagliari, California 09124, Italy
}

a) Author to whom any correspondence should be addressed: cjiang@odu.edu

\begin{abstract}
Dosage control of reactive oxygen and nitrogen species (RONS) is critical to low-temperature plasma applications in cancer therapy. Production of RONS by atmospheric pressure, nonequilibrium plasmas in contact with liquid may be modulated via plasma conditions including plasma treatment time and pulse voltage and repetition frequency. In this study, a terephthalic acid-based probe was used to measure hydroxyl radicals $\left[\mathrm{OH}_{(\mathrm{aq})}\right]$ in water exposed to plasma and to demonstrate that the $\mathrm{OH}_{(\mathrm{aq})}$ concentration increases linearly with treatment time. Fluorometric measurements of hydrogen peroxide concentration in plasma-activated water show a linear relationship between the $\mathrm{H}_{2} \mathrm{O}_{2}$ production rate and the pulse repetition frequency of the plasma. In vitro plasma treatment of cancer cells shows that pancreatic (Pan02) and breast (4T1-Luc) cancer cells have different sensitivities to plasma exposure. The dependence of Pan02 cell viability on plasma treatment time or pulse voltage is nonlinear. The system described here for generation and delivery of reactive oxygen species from a nanosecond pulsed plasma jet represents a promising alternative approach to cancer therapy.
\end{abstract}

Published under license by AIP Publishing. https://doi.org/10.1063/5.0020435

\section{INTRODUCTION}

Reactive oxygen and nitrogen species (RONS) generated by atmospheric pressure plasmas in cell culture media or on tissue surfaces induce cell proliferation, ${ }^{1-3}$ apoptosis, ${ }^{1,4,5}$ necrosis, ${ }^{6}$ or direct ablation of cells or micro-organisms, suggesting applications in diverse areas of biomedicine, including wound healing, cancer therapy, and sterilization. $^{7-9}$ Wide-ranging sensitivities of cancer and normal cells to cold atmospheric plasma treatment, reported by several groups, ${ }^{10-14}$ point to the potential for cold plasma in cancer therapy. ${ }^{14,15}$ For clinical applications, the ability to kill tumor cells while avoiding adverse effects on surrounding normal tissue offers a substantial benefit, and for cold-plasma-based therapies this means delivering RONS to the treatment site in quantities and concentrations that are lethal to the malignant cells, with lesser or minimal impact on healthy cells. ${ }^{16}$ This critical ability to apply proper doses of the plasma agents requires quantitative measurements and precise control of RONS production in the liquid medium around the target cells. Modulating RONS concentrations in water using helium or argon plasma jets was reported by Ogawa et al. ${ }^{17}$ and Oh et al. ${ }^{18}$ A dielectric barrier discharge (DBD) plasma jet powered by bipolar pulses of $7 \mathrm{kV}_{\mathrm{p}-\mathrm{p}}$ at $10 \mathrm{kHz}$ generates concentrations of long-lived RONS $\left(\mathrm{H}_{2} \mathrm{O}_{2}, \mathrm{NO}_{2}{ }^{-}\right.$, and $\left.\mathrm{NO}_{3}{ }^{-}\right)$and $\mathrm{O}_{2}$ in plasma-activated water (PAW) that are dependent on plasma exposure time (1-30 $\mathrm{min})$ and electrode-water gap distance $(15-80 \mathrm{~mm}){ }^{18}$ In this system, the $\mathrm{H}_{2} \mathrm{O}_{2}$ concentration is the highest for treatment distances shorter than $30 \mathrm{~mm} .{ }^{18}$ In addition, Oh et al. showed that combinations of $\mathrm{He}$ gas and plasma jets could modulate the concentrations of dissolved oxygen and RONS in extracellular media and thereby could influence the viability of treated skin cells. ${ }^{19}$ The variation in skin cell viability in vitro that results from the effects of oxidation, oxygenation, and deoxygenation underscores the importance of monitoring and controlling RONS concentrations for the development of cold-atmospheric-plasma-based modalities in cancer therapy. ${ }^{17-19}$ Many cold plasma studies use $\mathrm{AC},{ }^{7,13,17}$ radio frequency (RF), ${ }^{20}$ or microsecond-duration bipolar pulses ${ }^{18}$ for plasma generation, most likely because of the availability and low cost of these power sources. ${ }^{21}$ Nanosecond pulsed plasma jets have the potential to offer greater 
flexibility and a wider range of RONS-production modulations. Plasma generation with nanosecond pulsed power sources can be tuned with a matrix of power parameters (pulse duration, repetition frequency, and voltage) and their discharge stability and low gas temperature $(\sim 300 \mathrm{~K})$ compare favorably with the output of high frequency AC or RF discharge plasma generators. ${ }^{21}$ Reports of quantitative determinations of RONS produced by nanosecond, pulsed, atmospheric pressure plasma jets (ns-APPJs) at liquid interfaces, however, and in the context of biological cell treatments, are rare.

In this study, we investigate the impact of $\mathrm{OH}$ and $\mathrm{H}_{2} \mathrm{O}_{2}$ concentrations in ns-APPJ-activated liquid media on the viability of cancer cells in vitro. $\mathrm{OH}$ and $\mathrm{H}_{2} \mathrm{O}_{2}$ are among the dominant reactive oxygen species (ROS) in atmospheric-pressure plasma jets (APPJs) in contact with water, ${ }^{22}$ and they play central roles in aqueous-phase chemistry in plasma-activated liquid media for bacterial sterilization. ${ }^{23}$ The dependence of $\mathrm{OH}$ and $\mathrm{H}_{2} \mathrm{O}_{2}$ concentrations in water on plasma treatment conditions [time and pulse repetition frequency (PRF) and voltage] was investigated here using a 140-ns pulsed $\mathrm{He}$ plasma jet impinging on water. Effects of $\mathrm{OH}$ and $\mathrm{H}_{2} \mathrm{O}_{2}$ concentrations on the viability of pancreatic (Pan02) and breast (4T1-Luc) cancer cells were assessed in vitro with different plasma treatment times and pulse voltages.

\section{EXPERIMENTAL DESIGN AND METHODS}

\section{A. Nanosecond pulsed plasma source}

A nanosecond pulsed microplasma jet system, as shown in Fig. 1, was used to treat the cancer cells in liquid media. The high voltage needle electrode was made of a stainless-steel tube $(0.50 \mathrm{~mm}$ outer diameter and $0.26 \mathrm{~mm}$ inner diameter) that was connected to a high voltage pulsed power source through a coaxial transmission line (RG58U, characteristic impedance $=50 \Omega$ ). The plasma was impinging on a liquid surface in a cell of a 96-well plate placed on top of a copper plate, which had the same ground with the coaxial transmission line. Details of a similar electrode jet system was reported previously. ${ }^{24}$ The gap distance between the needle electrode outlet surface and the liquid surface was kept constant at $5 \mathrm{~mm}$ for all studies. The high voltage pulse generator (a solid-state pulse generator, custom-built by the Pulse Power Group at the University of Southern California) is capable of providing a constant pulse duration of $140 \mathrm{~ns}$ to the plasma system with a voltage amplitude of $\leq 10 \mathrm{kV}$ at a single shot or repetitive pulse rate of $\leq 10 \mathrm{kHz}$. Ultra-pure ( $>99.9999 \%)$ helium was used as the working gas and flew through the hollow needle electrode at a flow rate of 36 SCCM (standard cubic centimeter per minute), which was controlled by a calibrated rotameter. The same flow rate was used in all the studies. The current and voltage were measured at the output of the pulse generator with a wideband current monitor (Pearson 2877) and a high voltage probe (Tektronix 6015A) in connection with a digital oscilloscope, as shown in Fig. 1(a). With the plasma impinging on a cell suspension, typical voltage and current waveforms are shown in Fig. 1(b). The full width half maximum (FWHM) of the positive voltage pulse was measured to be $140 \mathrm{~ns}$. The pulsed current consists of both displacement and conduction components. Subtracting the current that was obtained when the helium flow was switched off (and the plasma was off) from the current when the plasma was on, we obtained the jet current that was corresponding to the conduction current, as shown in Fig. 1(b). Integrating the product of voltage and current over a sufficient period of time, e.g., $1.6 \mu$ s, yields the energy per pulse of $2.1 \mathrm{~mJ}$ for a $10-\mathrm{kV}$ pulsed plasma system. At $9 \mathrm{kV}$, the

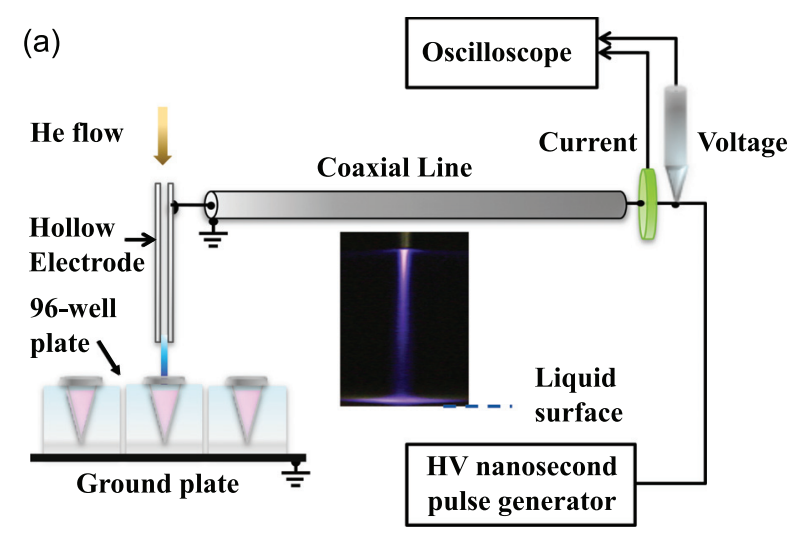

(b)

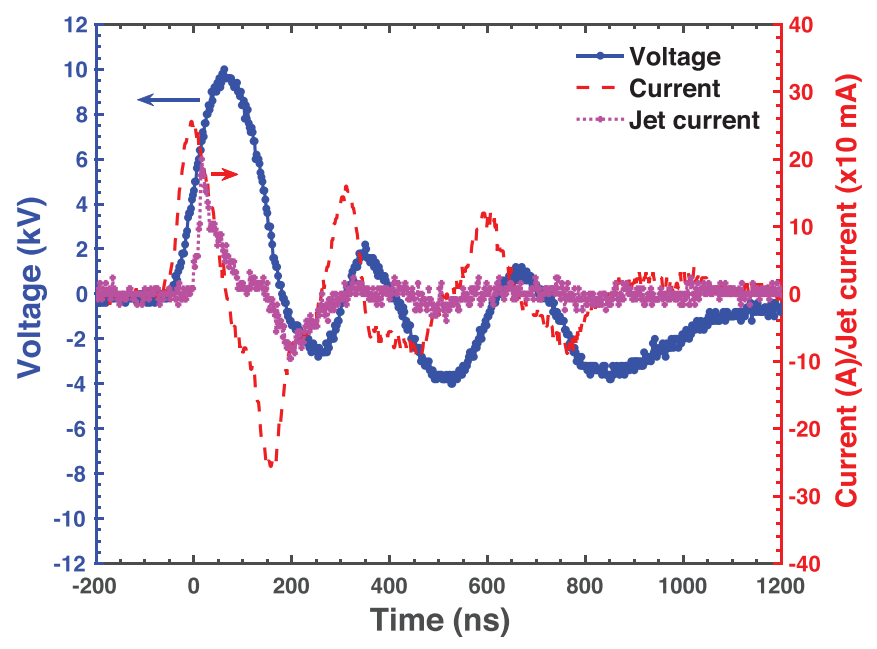

FIG. 1. (a) Experimental setup of the ns-APPJ treatment system indicating the voltage and current measurements as well as an image of the plasma impinging to liquid surface and (b) the typical voltage, current, and jet current waveforms of the plasma.

energy per pulse consumed by the plasma system was measured to be $1.7 \mathrm{~mJ}$.

\section{B. Hydroxyl radical measurements in gas and liquid phases}

In the gas phase, $\mathrm{OH}$ radicals can be either in excited or ground states. The excited $\mathrm{OH}(\mathrm{A})$ may relax to its ground state via $\mathrm{OH}(\mathrm{A}-\mathrm{X})$ transition and was observed via optical emission spectroscopy (OES) ${ }^{24}$ The ground state $\mathrm{OH}$ above the water surface was measured using laser induced fluorescence. Similar approaches to measure gas phase $\mathrm{OH}$ radicals were reported by others. ${ }^{25,26}$ The experimental setup is outlined in Fig. 2(a). The incident laser beam was generated by a dye laser (Spectra-Physics, Cobra-Stretch) that was pumped using a pulsed Nd:YAG laser (Spectra-Physics, Pro-250) at $532 \mathrm{~nm}$. The dye laser used Rhodamine $6 \mathrm{G}$ as the dye and was equipped with a frequency doubling crystal, allowing tuning of the laser wavelength 
(a)

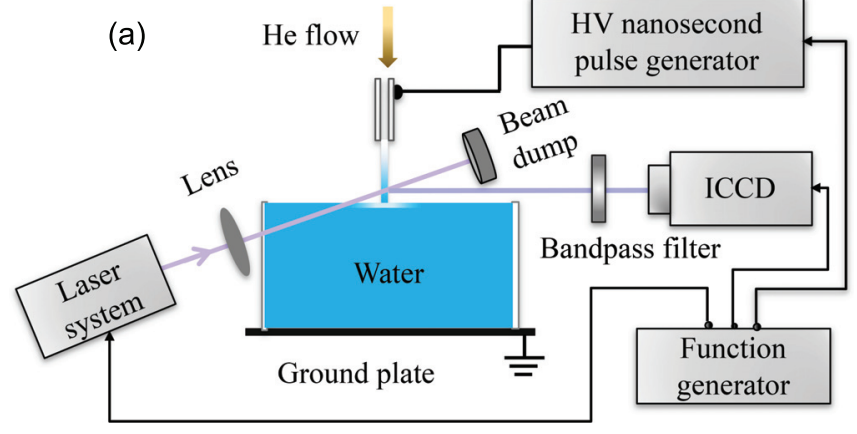

(b)

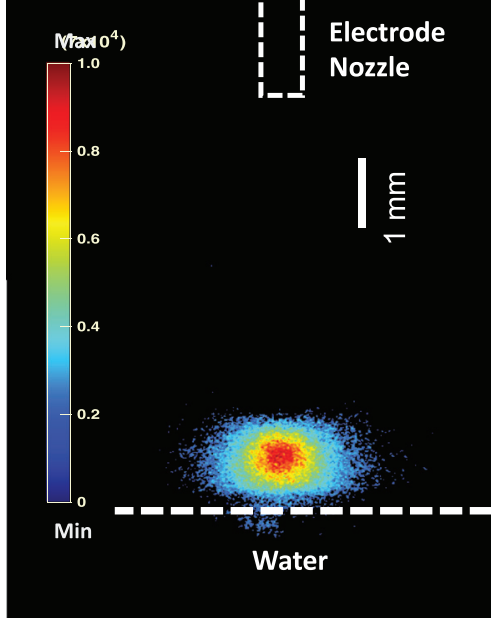

FIG. 2. (a) Schematic of the LIF setup for measurement of $\mathrm{OH}$ radicals in the gas phase generated by 140 -ns pulsed, 9 kV plasma impinging on water and (b) a LIF image based on 6000 accumulated exposures, where the laser beam was aligned within $1 \mathrm{~mm}$ above the water surface.

between 282 and $288 \mathrm{~nm}$ and a linewidth of $\sim 2 \mathrm{pm}$. For the LIF measurements, the center wavelength was set at $282.6 \mathrm{~nm}$, corresponding to the excitation transition from $\mathrm{OHX}\left(-\nu^{\prime \prime}=0\right)$ to $\mathrm{OH}(\mathrm{A})\left(\nu^{\prime}=1\right)$, at which the strongest fluorescence was detected. The laser pulse had a FWHM of $8 \mathrm{~ns}$ and was operated at $10 \mathrm{~Hz}$. The excitation laser beam was focused using a UV-visible lens (focus length $=50 \mathrm{~cm}$; diameter $=25.4 \mathrm{~mm}$ ) onto the plasma jet and the fluorescence was collected at a $90^{\circ}$ angle using an intensified CCD camera (ICCD, Princeton Instrument, PIMAX4i), after a bandpass filter centered at $309 \mathrm{~nm}$ with a full width half maximum (FWHM) of $10 \mathrm{~nm}$. As the emission was primarily observed within 308 and $309 \mathrm{~nm},{ }^{25}$ this bandpass filter was assumed to be sufficient for the LIF detection. The gate of the ICCD camera was set at $50 \mathrm{~ns}$. The pulsed laser, ICCD, and pulse generator powering the plasma were synchronized using a function generator (Stanford Research Systems, DG535) so that a temporally resolved LIF could be obtained. The laser beam width was measured to be $0.5 \mathrm{~mm}$ using Rayleigh scattering. The LIF plane was perpendicular to the axial direction ( $z$-direction) of the plasma jet and $<1 \mathrm{~mm}$ above the water surface. A typical LIF image based on 6000 exposures is shown in Fig. 2(b). The LIF image was corrected for the optical emission of the plasma by subtracting the plasma emission with the laser off from that with the laser on.

The $\mathrm{OH}$ radical in the liquid phase $\mathrm{OH}_{(\mathrm{aq})}$ generated in plasmatreated water was measured using terephthalic acid $\left(\mathrm{TA}, \mathrm{C}_{8} \mathrm{H}_{6} \mathrm{O}_{4}\right)$ as an $\mathrm{OH}$ scavenger to form fluorescent molecule 2-hydroxyterephthalic acid (2-HTA). ${ }^{27}$ Details of this method for $\mathrm{OH}_{(\mathrm{aq})}$ measurements were reported previously. ${ }^{28}$ For this study, a $1.5-\mathrm{ml}$ centrifuge tube was used as the liquid container and placed on the ground plate. $2 \mathrm{mM} \mathrm{TA}$ stock solution was prepared by dissolving TA (Alfa Aeser, >98\%) with $14 \mathrm{mM} \mathrm{NaOH}$ and diluted in ultra-pure water to obtain a final TA concentration of $200 \mu \mathrm{M}$. Note that the TA concentration $200 \mu \mathrm{M}$ was determined to be in significant excess of what is needed for measurements of $\mathrm{OH}_{(\mathrm{aq})}$ with concentrations $\leq 10 \mu \mathrm{M},{ }^{27,29}$ so that the TA concentration would not affect the measurements. ${ }^{29-31}$ For the experiment, $0.5 \mathrm{ml}$ of the TA solution was added to the centrifuge tube. Seven treatment groups including three control and four plasma treatment groups with 3-9 repeats in each group were used for the study. The control groups include measurements for blank/empty vessels, for ultra-pure water, and for water exposed to He flow for $300 \mathrm{~s}$. During the plasma treatment, the discharge voltage was kept constant at $10 \mathrm{kV}$ and the pulse repetition frequency (PRF) was $2 \mathrm{kHz}$.

After treatment, $300 \mu \mathrm{l}$ of the solutions from each centrifuge tube was transferred to three different wells $(3 \times 100 \mu \mathrm{l})$ of black-wall 96-well plates to allow repeated measurements. 2-HTA fluorescence was collected using a plate reader (Molecular Devices SpectraMax i3) equipped with excitation and emission wavelengths: $\lambda \mathrm{ex}=310 \mathrm{~nm}$ and $\lambda \mathrm{em}=425 \mathrm{~nm}$. Calibration was obtained by recording the fluorescence under the same measurement conditions for a range of known concentrations of 2-HTA solutions. Stock solution of 2 mM 2-HTA (Tokyo chemical industry, >98\%) in phosphate buffer solution (PBS) was diluted in ultra-pure water to generate the concentrations needed for the calibration. ${ }^{28}$ Fluorescence was recorded approximately $10 \mathrm{~min}$ after treatment as the "first read." The fluorescence emission was then recorded again $1 \mathrm{~h}$ and $2.5 \mathrm{~h}$ after, respectively. The emission intensities recorded at different post-treatment times were compared to understand the stability of 2-HTA in solution. We found that 2-HTA is stable for 2.5 hours after treatment and variations in results taken at different measurement times were negligible. Note that it is necessary to have the plasma operated at kilohertz PRF in order to have confident 2-HTA signals above the negative control or the baseline, as indicated in Sec. III B.

\section{C. $\mathrm{H}_{2} \mathrm{O}_{2}$ measurements in plasma-activated water}

A fluorometer (O2k-Fluo LED2-Module) with a high-resolution respirometry apparatus (OROBOROS Instruments, Innsbruck, Austria) was used to measure the kinetics of $\mathrm{H}_{2} \mathrm{O}_{2}$, generated by the plasma, in ultra-pure water (conductivity $=0.055 \mu \mathrm{S} / \mathrm{cm}$ at $25^{\circ} \mathrm{C}$ ). The plasma needle electrode was positioned $5 \mathrm{~mm}$ above the surface of $4-\mathrm{ml}$ ultrapure water within the chamber of a respirometer, which was equipped with a polarographic electrode allowing measurements of the oxygen concentration in the chamber. The concentrations of the chemicals used in these experiments are referred to the volume of the ultrapure water within the $\mathrm{O} 2 \mathrm{k}$ chamber. The water was maintained at the temperature of $37^{\circ} \mathrm{C}$ with a constant agitation at $750 \mathrm{rpm}$ during the tests to ensure the measurement accuracy and fast response time $(<0.1 \mathrm{~s})$. The $\mathrm{O} 2 \mathrm{k}-$ fluorometer detected fluorescence intensity changes of the resorufin compound produced by the reaction between $\mathrm{H}_{2} \mathrm{O}_{2}$ and Amplex 
UltraRed (AmR, $5 \mu \mathrm{M}$ ), which was catalyzed by horse radish peroxidase (HRP, $5 \mathrm{U} \mathrm{ml}^{-1}$ ). The intensity of the fluorescence emitted by resorufin was proportional to the concentration of $\mathrm{H}_{2} \mathrm{O}_{2}$ in the media. Following a similar assay by Krumschnabel et al., ${ }^{32}$ a calibration of the fluorescent signal was obtained by adding $\mathrm{H}_{2} \mathrm{O}_{2}$ to the solution to have a final concentration of $0.1 \mu \mathrm{M}$. The DatLab software (OROBOROS Instruments, Innsbruck, Austria) was used to calculate the real-time $\mathrm{H}_{2} \mathrm{O}_{2}$ molar flow rate from the time derivative of the resorufin signal.

The plasma jet was operated at a pulse voltage of 9 or $10 \mathrm{kV}$ with repetition frequencies (PRFs) in the range of $1-10 \mathrm{~Hz}$. Operating at higher PRFs led to a rapid change of the fluorescence signal exceeding the preset calibration limit. With the plasma jet impinging on the water surface of the $\mathrm{O} 2 \mathrm{k}$ chamber, the fluorescence intensity was recorded in real time and a steady state was reached at each treatment condition to determine the production rate of $\mathrm{H}_{2} \mathrm{O}_{2}$ in water. The fluorescence signal recorded with helium jet (where plasma was turned off) was used as the background to compare the signal when the plasma was turned on.

\section{Treatment of cancer cells in vitro}

Effects of the ns-APPJ on the viability of a murine pancreatic adenocarcinoma (Pan02) were evaluated in vitro by applying different plasma treatment times or pulse voltages to cells. In addition, ns-APPJ inactivation on Pan02 cells was compared with breast cancer (4T1luc) cells to evaluate the cell-specific response to the plasma treatment.

\section{Cell culture}

Pan02 cell lines were provided by the Division of Cancer Treatment and Diagnosis (DCTD, NCI) and maintained in RPMI1640 (ATCC $^{\circledR} 30-2001^{\mathrm{TM}}$ ) supplemented with $10 \%$ fetal bovine serum (FBS) (Atlantic Biological), $100 \mathrm{IU}$ of penicillin, and $100 \mu \mathrm{g} / \mathrm{ml}$ streptomycin. 4T1-luc breast cancer cells were purchased from Dr. G. Sahagian at Tufts University and maintained in high glucose DMEM (ATCC 30-2002) that was supplemented with 10\% FBS, non-essential amino acids (NEAA), and antibiotics (100 units/ml penicillin and $100 \mu \mathrm{g} / \mathrm{ml}$ streptomycin). Both 4T1-luc and Pan02 cells were cultured in a $37^{\circ} \mathrm{C}$ incubator supplied with $5 \% \mathrm{CO}_{2}$. Prior to the plasma treatment, $100 \mu$ cells $\left(1 \times 10^{5} / \mathrm{ml}\right)$ were seeded in each well of a 96-well plate and cultured overnight.

\section{Plasma treatment}

Overnight incubated cells were plated in a 96-well plate with $100 \mu \mathrm{l}$ cell suspension per well. Two controls were used to evaluate the significance of the treatment outcome. One control group was left untreated and the other was treated with helium flow for $120 \mathrm{~s}$. Both 4T1-luc and Pan02 cells were treated with plasma for 30, 60, and 120 $\mathrm{s}$. To further assess the impact of plasma exposure time and pulse voltage on cancer cells, Pan02 cells were also treated with plasma for 5, 15, $90 \mathrm{~s}$ and at different pulse voltages of $7,8,9 \mathrm{kV}$. The standard plasma conditions were kept at $10 \mathrm{kV}, 2 \mathrm{kHz}$, and nozzle-to-liquid gap distance of $5 \mathrm{~mm}$, to be consistent with the $\mathrm{OH}_{(\mathrm{aq})}$ measurements.

\section{Cell viability assay}

WST-1 cell viability assay ${ }^{33}$ was carried out in this in vitro study. Immediately after plasma treatment, cells were incubated at $37^{\circ} \mathrm{C}$ and
$5 \%$ of $\mathrm{CO}_{2}$ for $18 \mathrm{~h}$. After adding $10 \mu \mathrm{l}$ WST-1 reagent to each well, cells were incubated for another $2 \mathrm{~h}$. Viability assessment was undertaken based on fluorescence measurements using a MultiSkan MCC/ 340 microplate reader (Fisher Scientific, Hampton, NH) with an excitation wavelength of $450 \mathrm{~nm}$ and a reference wavelength of $630 \mathrm{~nm}$. The cell viability (\%) was calculated using the formula: treated sample $(\mathrm{OD} 450$ - OD630)/control (OD450 - OD630) $\times 100 \%$. Cells that were left untreated were used as control.

\section{Statistical analysis}

Results are expressed as mean \pm SD (standard deviation) of at least five repeated experiments. Statistical analysis was performed using one-way analysis of variance (ANOVA). $P<0.001$ was considered significant.

\section{RESULTS}

\section{A. $\mathrm{OH}$ in gas phase}

Figure 3 shows a spatiotemporally resolved OH-LIF signal near the water surface. Each measurement was obtained from 6000 accumulated LIF images. At the radial center and $\sim 0.8 \mathrm{~mm}$ above the water surface, the measurement of the temporal development of the $\mathrm{OH}$ radicals showed that the production of $\mathrm{OH}$ reached its maximum at $t_{\mathrm{d}}=50 \mathrm{~ns}$, with $t_{\mathrm{d}}$ noted as the delay time after the onset of the plasma. The $\mathrm{OH}$ density decreased quickly during the following $50 \mathrm{~ns}$ and the decay slowed down between $t_{\mathrm{d}}=100 \mathrm{~ns}$ and $300 \mathrm{~ns}$, as shown in Fig. 3(a). Comparing with the jet current, the LIF signal aligned with the current at beginning as well as the decay phases. Due to the detector's sensitivity, the minimum time interval of the LIF signal was set at $50 \mathrm{~ns}$, resulting in the LIF peak appearing different from the current peak during the first $50 \mathrm{~ns}$. Measurements of $\mathrm{OH}$ radicals near the water surface at a delay time of 50 ns revealed a radially quasisymmetrical profile, although the symmetry was not perfect, as shown in Fig. 3(a). This imperfection in radial symmetry was possibly due to the leveling of the electrode nozzle surface with respect to the water surface.

The LIF and previous $\mathrm{OES}^{24}$ measurements showed the presence of $\mathrm{OH}$ radicals above the water surface. The temporal development of $\mathrm{OH}-\mathrm{LIF}$ revealed that the majority of ground state $\mathrm{OH}$ was produced during the rising phase of the voltage pulse, which corresponded to the primary positive current pulse, and the gas phase $\mathrm{OH}$ radicals were relatively short lived, $\sim 300 \mathrm{~ns}$. Near the gas-liquid interface, electron dissociation as well as electron-ion dissociative recombination would play the most important role in $\mathrm{OH}$ production, followed by other mechanisms including dissociative attachment, positive-negative ion recombination, and water ion hydration. ${ }^{34}$ These liquid-water interface $\mathrm{OH}$ radicals were considered to be primarily responsible for the production of $\mathrm{H}_{2} \mathrm{O}_{2}$ in liquid via recombination for plasma-treated water. ${ }^{23}$ Hence, the absolute density of gas phase $\mathrm{OH}$ was not pursued in this study. The kinetics of $\mathrm{H}_{2} \mathrm{O}_{2}$ produced by the plasma in water is presented in Sec. II C.

\section{B. Dosage-dependent $\mathrm{OH}_{(\mathrm{aq})}$ production in water}

2-HTA formed in the TA solution is stable and the concentration difference among different emission recording times, i.e., $<30 \mathrm{~min}$ or $<3 \mathrm{~h}$ after the treatment, is negligible, as shown in Fig. 4(a). The measurements of 2-HTA concentration for blank vessels indicated the 
(a)

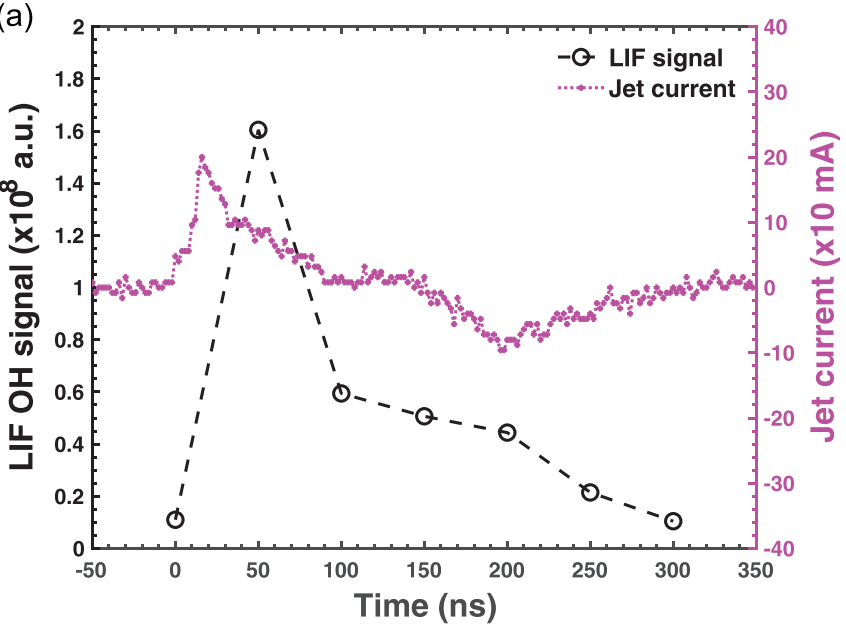

(b)

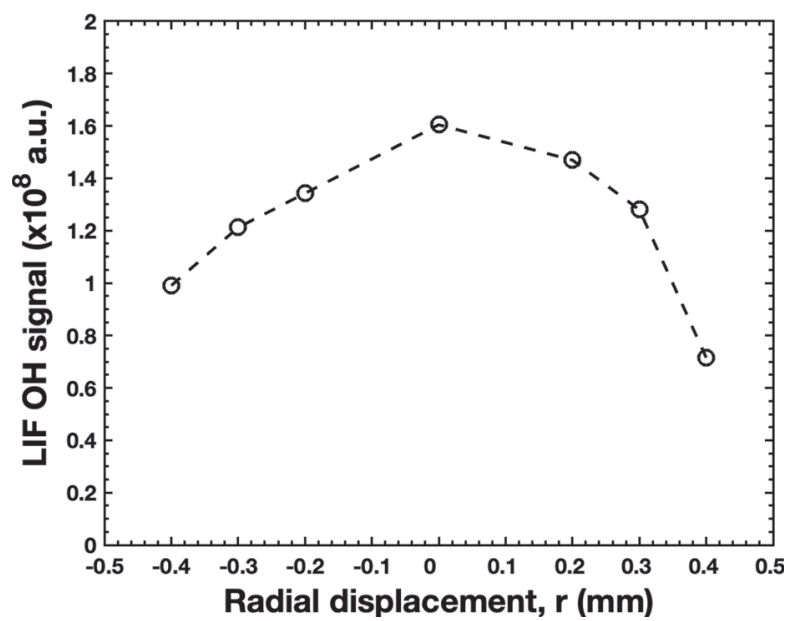

FIG. 3. (a) Temporal development OH-LIF emission at the radial center and $<1 \mathrm{~mm}$ above the water surface, comparing with the jet current at the same timescale and (b) the radial distribution of the $\mathrm{OH}-\mathrm{LIF}$ emission at a delay time of $t_{\mathrm{d}}=50 \mathrm{~ns}$ and the same axial location.

sensitivity of this method, which was $0.07 \mu \mathrm{M}$. The average HTA concentrations for water or helium-treated water were measured to be 0.19 and $0.14 \mu \mathrm{M}$, respectively, and hence have no significant difference. Based on these control measurements, the baseline of this HTA concentration would be $\sim 0.2 \mu \mathrm{M}$. Plasma treatment for $30 \mathrm{~s}$ resulted in an increase in HTA concentration to $0.8 \mu \mathrm{M}$ and the longer the plasma exposure, the higher the concentration. Figure 4(b) showed a linear dependence of the HTA concentration on the plasma treatment time. The linear fitting intercepts at a HTA concentration of $0.2-0.3 \mu \mathrm{M}$, corresponding to the baseline from the negative control. If we follow others $\mathrm{s}^{27,30,31}$ and assume that $35 \% \mathrm{OH}$ reacted with TA to form 2-HTA, ${ }^{30,31}$ the $\mathrm{OH}_{(\mathrm{aq})}$ concentration in water as a function of plasma treatment time can also be obtained, referring to the right $y$-axis in Fig. 4(b). Considering the plasma was operated at $2 \mathrm{kHz}$, the linear fitting indicated that the background-subtracted $\mathrm{OH}_{(\mathrm{aq})}$ (a)

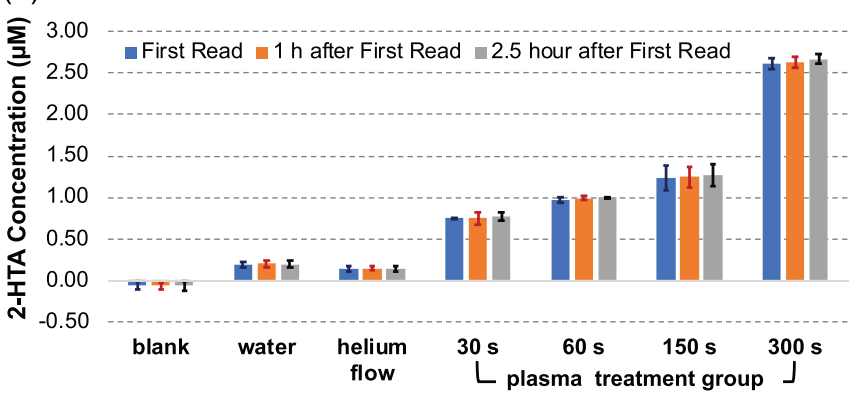

(b)

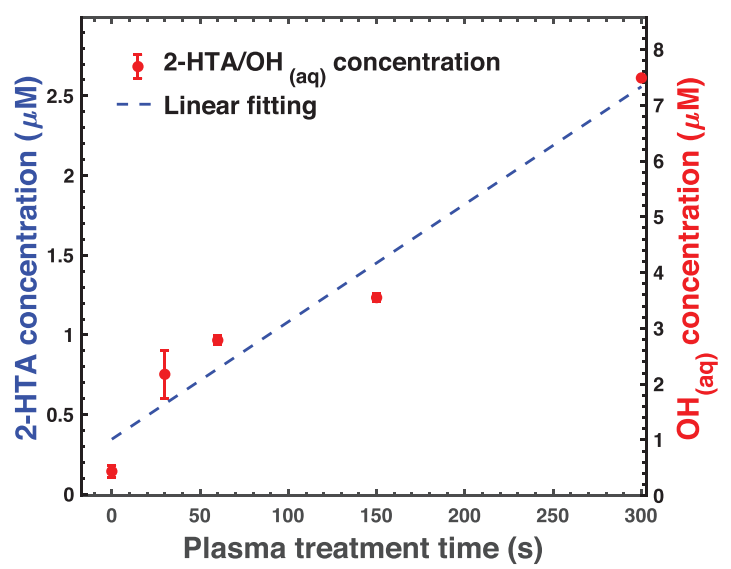

FIG. 4. 2-HTA concentration in water indicating $\mathrm{OH}_{(\mathrm{aq})}$ production by plasma: (a) 2HTA concentration in water for different treatment groups, measured at different post-treatment times, and (b) the linear dependence of the 2-HTA (the left $y$-axis) and the corresponding $\mathrm{OH}_{\text {(aq) }}$ (the right $y$-axis) concentration in water on plasma treatment time, based on the "first-read" measurements. The 2-HTA measurements with helium-flow were used as the zero-treatment time or the control in (b). The plasma was operated at $10 \mathrm{kV}, 2 \mathrm{kHz}$. Note that the $\mathrm{OH}_{(\text {aq) }}$ concentration was in fact the production of $\mathrm{OH}_{(\mathrm{aq})}$ in water that was trapped by TA to form HTA, not the actual concentration in the solution.

concentration was $1.4 \mu \mathrm{M}$ in a $0.5-\mathrm{ml}$ solution after 60 -s plasma treatment. If we assume that the $\mathrm{OH}_{(\mathrm{aq})}$ concentration accumulates linearly as PRF, the $\mathrm{OH}_{(\mathrm{aq})}$ production by plasma of each pulse could be estimated to be $0.006 \mathrm{pmol}$ in the $0.5-\mathrm{ml}$ PAW.

\section{Dosage-dependent $\mathrm{H}_{2} \mathrm{O}_{2}$ production}

With the pulse repetition frequency increasing from 2 to $10 \mathrm{~Hz}$, the $\mathrm{H}_{2} \mathrm{O}_{2}$ production rate increased linearly for a pulse voltage of $9 \mathrm{kV}$ (Fig. 5). At zero PRF, the $\mathrm{H}_{2} \mathrm{O}_{2}$ production rate, about $0.15 \mathrm{pmol} \mathrm{min}^{-1} \mathrm{ml}^{-1}$, corresponds to the control with only helium jet impinging to water and plasma was off. Increasing the pulse voltage to $10 \mathrm{kV}$, a similar linear dependence on the PRF was observed, although the $\mathrm{H}_{2} \mathrm{O}_{2}$ production rate at $10 \mathrm{kV}$ was about twice that at $9 \mathrm{kV}$ for the same PRF. The linear PRF dependence indicates that $\mathrm{H}_{2} \mathrm{O}_{2}$ was generated at a constant rate by the plasma for a given pulse voltage in dependent of PRF. For instance, at $10 \mathrm{kV}$, the plasma produced $0.80 \mathrm{pmol} \mathrm{H}_{2} \mathrm{O}_{2} / \mathrm{ml}$ per min at a PRF of $2 \mathrm{~Hz}$, which 


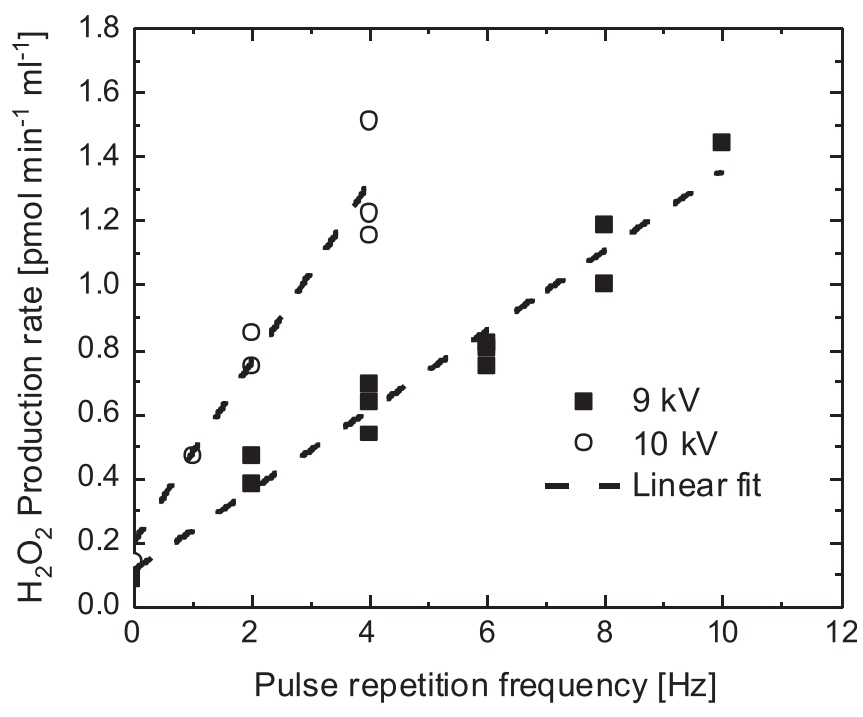

FIG. 5. $\mathrm{H}_{2} \mathrm{O}_{2}$ production rate in water during the plasma treatment with respect to the pulse repetition frequency for voltage pulses with amplitude of 9 or $10 \mathrm{kV}$. The dashed lines are linear fitting of the data. Zero PRF corresponds to the control where the plasma was turned off and only the helium jet was exposed to water.

corresponds to $0.027 \mathrm{pmol}$ of $\mathrm{H}_{2} \mathrm{O}_{2}$ generated by each pulse in 4-ml water. At $9 \mathrm{kV}$, the production rate was half of that at $10 \mathrm{kV}$ and 0.013 pmol of $\mathrm{H}_{2} \mathrm{O}_{2}$ generated by each pulse in 4-ml water. In addition, the oxygen concentration within the chamber was monitored during the study. After an initial stripping of oxygen due to the helium flux (as the carry gas) in contact with water, the oxygen concentration remained constant during plasma treatment for different PRFs or pulse voltages. It was hence safe to deduce that the pulsed plasma under these tested conditions has negligible effect on the oxygen concentration in water.

\section{Cancer cell inactivation by ns-APPJs in vitro}

Viability study of exposing Pan02 and 4T1-Luc cells in liquid media to plasma for different time durations, i.e., 30, 60, and $120 \mathrm{~s}$, displayed a dosage dependence of the cell survival for both cells lines; the longer the plasma treatment time, the less cells survived, as shown in Fig. 6. In addition, 4T1-Luc cells appeared more sensitive to the plasma treatment time compared to Pan02. After 60-s plasma treatment, 28\% ( $\pm 28 \%)$ 4T1-Luc cells survived, whereas Pan02 cells had $73 \%( \pm 16 \%)$ survival rate. After 120 -s plasma treatment, the survival rate of $4 \mathrm{~T} 1$-Luc reduced to $2.7 \%$ ( $\pm 0.8 \%$ ), about half of Pan02, which was $5.5 \%( \pm 1.1 \%)$. This different susceptibility of cells to plasma was also observed by others. ${ }^{14}$ More detailed examination of the viability of Pan02 cells on plasma treatment time, as shown in Fig. 7, however, revealed that the dependence was not linear. It seemed that there was a "threshold" plasma treatment time (e.g., $\sim 60 \mathrm{~s}$ for Pan02), less than which the killing effect was negligible. When the treatment time exceeded the threshold treatment time, the plasma-induced cell death became significant; for this study, there were less than $10 \%$ cells survived after 90 -s or 120 -s treatment. Keeping a constant treatment time, varying the plasma voltage can also modulate the production of ROS, as shown in the $\mathrm{H}_{2} \mathrm{O}_{2}$ measurements in Sec. III C. Figure 8

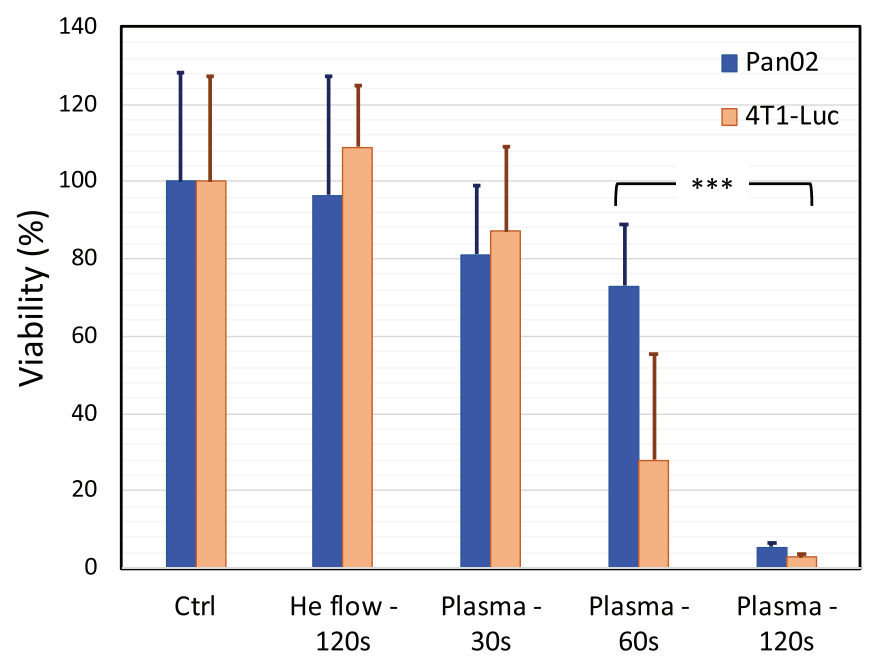

FIG. 6. Viability of pancreatic (Pan02) and breast (4T1-luc) cancer cells, after exposure to plasma for 30,60 , and $120 \mathrm{~s}$. The plasma was powered at $10 \mathrm{kV}, 2 \mathrm{kHz}$. Untreated (Ctrl) and treated by helium flow for $120 \mathrm{~s}$ (He flow-120 s) are the control groups. Error bars represent standard deviations $(n=5)$. ${ }^{* * *} P<0.001$ for "plasma-120 s" and "plasma-60 s" for both cell lines by one-way ANOVA.

shows that a similar rate of Pan02 inactivation was achieved after 120s plasma treatment with various voltages from 8 to $10 \mathrm{kV}$. Reducing the plasma voltage to $7 \mathrm{kV}$ resulted in a higher survival rate of $22 \%$ compared to other plasma treatment groups at $5 \%-8 \%$. Lower voltages than $7 \mathrm{kV}$ were not used as the plasma became unstable or failed to initiate when the voltage was furtherly reduced.

\section{DISCUSSION}

It is known that oxygen and nitrogen-based radicals including $\mathrm{OH}, \mathrm{NO}$, and $\mathrm{NO}_{2}$ in plasma-activated water (PAW) are important but short-lived. ${ }^{22,23}$ Their interactions with the cells in a medium are

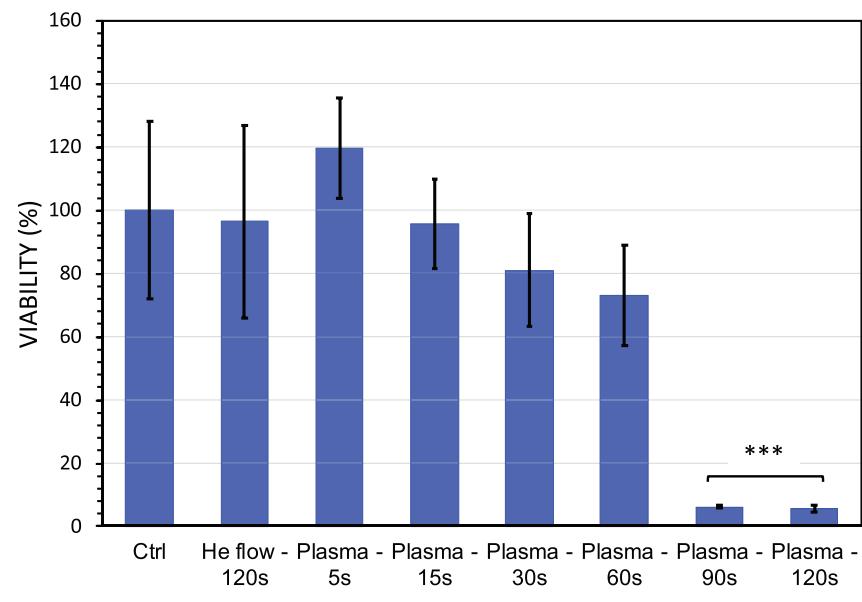

FIG. 7. Viability of Pan02 cancer cells for different plasma treatment times. The plasma was powered at $10 \mathrm{kV}, 2 \mathrm{kHz}$. The zero-plasma treatment time corresponds to the two controls, the untreated and 120-s helium treatment groups. Error bars represent standard deviations $(n=5)$. ${ }^{* *} p<0.001$ for 90 and 120 -s plasma treatment groups vs all other groups by one-way ANOVA. 


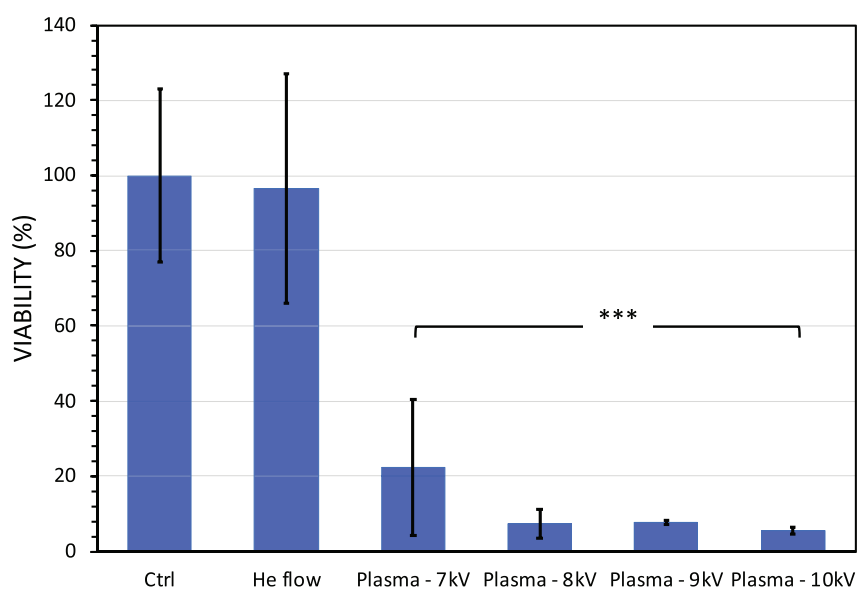

FIG. 8. Viability of Pan02 cells after 120 -s treatment of ns-APPJs that was powered by various voltages ranging from $7 \mathrm{kV}$ to $10 \mathrm{kV}$ at a constant PRF of $2 \mathrm{kHz}$. The control includes the untreated (Ctrl) and 120-s helium treatment (He flow) groups. The error bars represent standard deviations $(n=5) .{ }^{* * *} p<0.0001$ for the plasma treatment groups vs the control groups (untreated and $\mathrm{He}$ flow) by one-way ANOVA.

primarily through forming long-lived species including hydrogen peroxide, nitrites, and nitrates, who would play more important roles in inducing biological effects. ${ }^{23}$ If we assume that the production of $\mathrm{H}_{2} \mathrm{O}_{2}$ in PAW is linearly dependent on the pulse repetition frequency and extrapolate the $\mathrm{H}_{2} \mathrm{O}_{2}$ production rate to $2 \mathrm{kHz}$, a single-pulse ns-APPJ produces $0.027 \mathrm{pmol} \mathrm{H}_{2} \mathrm{O}_{2}$ and a treatment at $2 \mathrm{kHz}$ for $60 \mathrm{~s}$ would produce $3.2 \mathrm{nmol}$ of $\mathrm{H}_{2} \mathrm{O}_{2}$ in $4-\mathrm{ml} \mathrm{PAW}$. As the majority (or $70 \%$ according to the measurements by Zhao et al. ${ }^{35}$ ) of $\mathrm{H}_{2} \mathrm{O}_{2}$ was formed by recombination of $\mathrm{OH}$ at the gas-liquid interface via the following reaction: ${ }^{23}$

$$
\mathrm{OH}+\mathrm{OH} \rightarrow \mathrm{H}_{2} \mathrm{O}_{2},
$$

at least $4.5 \mathrm{nmol}$ of $\mathrm{OH}$ has to be produced at the interface in order to fulfill the $\mathrm{H}_{2} \mathrm{O}_{2}$ production. The production of $\mathrm{OH}$ radicals near the gas-liquid interface was largely attributed to electronic processes, including electron dissociation and electron-ion dissociative recombination, in addition to water-ion hydration and positive-negative ion recombination. ${ }^{22,34}$ It is hence expected that the production of gas phase $\mathrm{OH}$ radicals by plasma is greater than $1 \times 10^{12} \mathrm{~cm}^{-3}$, which is a converted density from a liquid concentration of $1.1 \mu \mathrm{M}$ (or $4.5 \mathrm{nmol}$ $\mathrm{OH}$ in $4 \mathrm{ml}$ water) following Henry's law and assuming $30 \mathrm{M} / \mathrm{bar}$ as Henry's constant for $\mathrm{OH}^{36}$ An absolute measurement of $\mathrm{OH}$ density in a $35-\mu$ s pulsed helium APPJ using LIF showed that a peak density of $\mathrm{OH}$ radicals of $2.5 \times 10^{12} \mathrm{~cm}^{-3}$ was produced at the center of the plasma jet and the density increased more than 10 times with the $\mathrm{H}_{2} \mathrm{O}$ vapor density increasing in the helium flow. ${ }^{37}$ For the ns-APPJ, the electron density was measured to be in the range of $3 \times 10^{13}-1 \times 10^{14} \mathrm{~cm}^{-3.38}$. As the gas phase $\mathrm{OH}$ radical generation is closely related to electronic processes, it is expected that the density of $\mathrm{OH}$ is on the same order of electron density. ${ }^{34}$ Both of these observations support that abundant $\mathrm{OH}$ in gas phase must have been produced to yield the measured $\mathrm{H}_{2} \mathrm{O}_{2}$. In the liquid, in addition to the gas phase $\mathrm{OH}$ dissolving in water following Henry's law, reactions including heavy ion and neural species play important roles in the
$\mathrm{OH}_{(\mathrm{aq})}$ production. ${ }^{22,34}$ The measurements showed that a concentration of $1.4 \mu \mathrm{M}$ of $\mathrm{OH}_{(\mathrm{aq})}$ was produced in $0.5-\mathrm{ml}$ water by the ns-APPJ after 60 -s treatment, corresponding to a total $0.7 \mathrm{nmol} \mathrm{OH}_{(\mathrm{aq})}$. This mole number of $\mathrm{OH}_{(\mathrm{aq})}$ is small, about $15 \%$ of the amount of $\mathrm{OH}$ estimated at the gas-liquid interface to produce $3.2 \mathrm{nmol} \mathrm{H}_{2} \mathrm{O}_{2}$ via Eq. (1) under the same plasma conditions. This implies that a significant source of $\mathrm{H}_{2} \mathrm{O}_{2}$ in liquid may be formation of $\mathrm{H}_{2} \mathrm{O}_{2}$ in the gas phase via $\mathrm{OH}$ recombination [Eq. (1)], followed by solvation of $\mathrm{H}_{2} \mathrm{O}_{2}$, which has a very high Henry's law constant (on the order of $10^{4}$ ). ${ }^{36}$ In addition, the different experimental conditions used for the measurements may also account for the difference in $\mathrm{OH}_{(\mathrm{aq})}$ and interface $\mathrm{OH}$ estimations. For the fluorometry method in determining $\mathrm{H}_{2} \mathrm{O}_{2}$, the electrode of the ns-APPJ was mostly contained in the respirometer chamber, creating a semienclosed system and preventing diffusion of gas phase $\mathrm{OH}$ and $\mathrm{H}_{2} \mathrm{O}_{2}$ to the ambient air, whereas for the measurement of $\mathrm{OH}_{(\mathrm{aq})}$, the ns-APPJ was impinging to the liquid surface in open air and more loss of $\mathrm{OH}$ would have occurred.

It was reported that intracellular ROS were induced after APPJ treatment of cells covered in a medium. ${ }^{1,4,5,39}$ Although direct quantitative relationship between the exogenous ROS, which was produced by plasma outside of cells, and the endogenous ROS, which was linearly related to the cellular response for a relatively high ROS dosage sufficient to harm cells, ${ }^{40}$ has not been determined, plasma-induced lipid oxidation and cellular membrane collapse ${ }^{41}$ as well as DNA damage $\mathrm{e}^{5}$ indicated a strong linkage between the two. In particular, a higher amount of $\mathrm{H}_{2} \mathrm{O}_{2}$ production in a pulsed plasma-treated culture medium was observed to be associated with lower survival of human mesenchymal stem cells. ${ }^{42}$ Although plasma-induced biological effects cannot be simply regarded as oxidation due to $\mathrm{H}_{2} \mathrm{O}_{2}$ or RONS, a sufficient amount of RONS may be needed to "disintegrate" the cells via cell membrane permeabilization. It is hence possible that the "threshold" in plasma treatment time is needed to reach sufficient ROS to trigger the cell "disintegration."

The application of different pulse voltages would result in different concentrations of $\mathrm{H}_{2} \mathrm{O}_{2}$ and $\mathrm{OH}$ radicals produced in the liquid. It was expected that the lower inactivation rate was associated with lower pulse voltage, which was the case when comparing 7 and $8 \mathrm{kV}$ plasma treatment groups (Fig. 8). On the other hand, the application of voltages higher than $8 \mathrm{kV}$ seemed not to increase the inactivation rate further, although the $\mathrm{H}_{2} \mathrm{O}_{2}$ production was expected to increase with voltage, e.g., by $\sim 2$ folds with voltage increasing from 9 to $10 \mathrm{kV}$ (Fig. 5). After all, more studies including investigation of the intracellular ROS dependence on pulse voltage are needed in order to understand the observed voltage-dependent cell inactivation effect.

Among the extracellular ROS studied here, the temporal development of the OH-LIF signal [Fig. 3(a)] showed that the lifetime of the ground state $\mathrm{OH}$ is about $300 \mathrm{~ns}$. It is hence not possible for $\mathrm{OH}$ radical to accumulate between pulses at a PRF of $2 \mathrm{kHz}$; the density of $\mathrm{OH}$ radicals produced at $2 \mathrm{kHz}$ is the same as with a single pulse. In the liquid phase, the lifetime of $\mathrm{OH}$ radicals was estimated to be a couple of milliseconds, ${ }^{22}$ which would allow accumulation of its density in liquid at a PRF of $2 \mathrm{kHz}$. However, this accumulation may not be linear as the $\mathrm{OH}$ concentration may already have started decay in $500 \mu \mathrm{s}$; the estimation of $0.006 \mathrm{pmol}$ of $\mathrm{OH}$ produced by each pulse may in fact be lower than its actual value. In comparison, $\mathrm{H}_{2} \mathrm{O}_{2}$ has a much longer lifetime, tens of seconds ${ }^{22}$ or minutes, ${ }^{23}$ and is able to accumulate in liquid. 


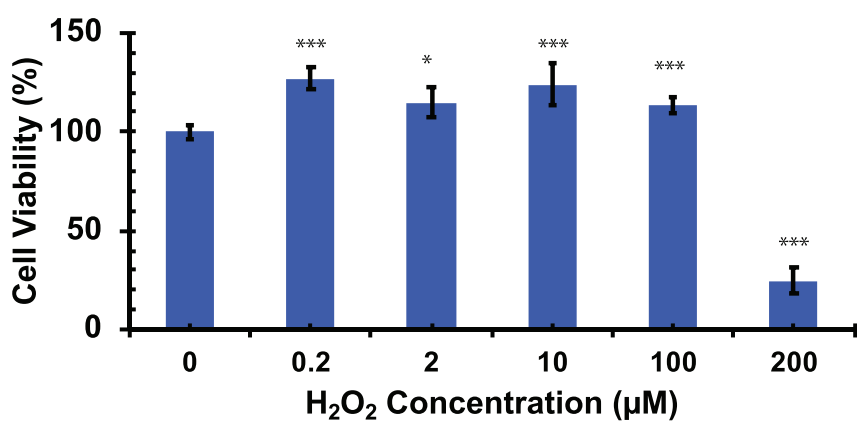

FIG. 9. Viability of Pan02 cells treated with various concentrations of $\mathrm{H}_{2} \mathrm{O}_{2}$. Error bars represent standard deviations $(n=5)$. $* * * p<0.001$ or $* p<0.05$ for the $\mathrm{H}_{2} \mathrm{O}_{2}$ groups vs the control groups) by one-way ANOVA.

To address whether the amount of $\mathrm{H}_{2} \mathrm{O}_{2}$ in the PAW is sufficient to induce cell death, an additional experiment was conducted by applying the same cell viability assay to Pan02 cells that were treated with $\mathrm{H}_{2} \mathrm{O}_{2}$ solutions alone. Cell viability with respect to $\mathrm{H}_{2} \mathrm{O}_{2}$ concentrations ranging from 0.2 to $200 \mu \mathrm{M}$ is shown in Fig. 9. Noticeably, $\leq 100 \mu \mathrm{M} \mathrm{H}_{2} \mathrm{O}_{2}$ did not reduce and in fact slightly increased the viability of Pan02 cells. Low concentrations of $\mathrm{H}_{2} \mathrm{O}_{2}$ may enhance cell viability by serving as a signal molecule for growth stimulation. ${ }^{43}$ Increasing the $\mathrm{H}_{2} \mathrm{O}_{2}$ concentration to $200 \mu \mathrm{M}$ reduced the viability to $25 \%$, similar to the inactivation results obtained from the $7 \mathrm{kV}, 120 \mathrm{~s}$ plasma treatment. However, the $\mathrm{H}_{2} \mathrm{O}_{2}$ concentration in the $2 \mathrm{kHz}$ plasma-activated water was calculated to be in the range of a few $\mu \mathrm{M}$, which is far from sufficient if $\mathrm{H}_{2} \mathrm{O}_{2}$ is acting alone to inactivate the cells. It is thus important to evaluate the role of $\mathrm{H}_{2} \mathrm{O}_{2}$ in combination with other long-lived RONS species (e.g., peroxynitrite and ozone ${ }^{23}$ ) in PAW for cancer cell inactivation. Importantly, the results also suggest that there may be a synergistic effect of long-lived RONS and electric field on the viability of cells, which requires more systematic studies in the future.

\section{CONCLUSION}

Control of extracellular ROS production for dosage-dependent cell inactivation by ns-pulsed APPJ was investigated in vitro. Adjusting the pulse parameters of the ns-APPJ allows production of $\mathrm{H}_{2} \mathrm{O}_{2}$ in water at several $\mathrm{pM}$ sensitivities. This was demonstrated by measurements of $\mathrm{H}_{2} \mathrm{O}_{2}$ formation kinetics in plasma-activated water and determining that 7 and $3 \mathrm{pM}$ of $\mathrm{H}_{2} \mathrm{O}_{2}$ are produced in $4 \mathrm{ml}$ PAW with each pulse at $10 \mathrm{kV}$ or $9 \mathrm{kV}$, respectively. The linear dependence of $\mathrm{OH}_{(\mathrm{aq})}$ concentration in water on the plasma treatment time was also identified. Although the production of $\mathrm{H}_{2} \mathrm{O}_{2}$ and $\mathrm{OH}$ radicals can be modulated by tuning the plasma generation conditions (pulse voltage and repetition frequency) and treatment time, the viability of Pan02 and 4T1-luc cells in plasma-treated medium has a nonlinear dependence on the treatment time and pulse voltage. While the "threshold" treatment time to achieve significant inactivation supports the importance of ROS in cell inactivation, the lower sensitivity at higher pulse voltages points to the need for additional studies to determine the dependence of intracellular ROS levels and other indicators of cell redox homeostasis on plasma treatment conditions.

\section{AUTHORS' CONTRIBUTIONS}

All authors made significant contributions to this work. C.J. designed and participated in all the experiments, data analysis, and documentations. E.B.S. designed and performed the experiment, data analysis, and documentation of $\mathrm{OH}_{(\mathrm{aq})}$ measurements. S.S. designed and performed the experiment and data analysis of OH-LIF measurements. N.L. designed and performed the experiment, data analysis, and documentation of $\mathrm{H}_{2} \mathrm{O}_{2}$ measurements as well as participated in the documentation of the paper. P.T.V. participated in the design of $\mathrm{OH}_{(\mathrm{aq})}$ measurements and the documentation of the paper. S.G. designed and performed the experiment, data analysis, and documentation of the inactivation of cancer cells.

\section{ACKNOWLEDGMENTS}

This material is based upon work supported by the U.S. Air Force Office of Scientific Research under Grant No. FA9550-171-0257. E.B.S. and P.T.V. received support from AFOSR MURI Grant No. FA9550-15-1-0517.

\section{DATA AVAILABILITY}

The data that support the findings of this study are available from the corresponding author upon reasonable request.

\section{REFERENCES}

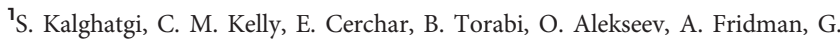
Friedman, and J. Azizkhan-Clifford, "Effects of non-thermal plasma on mammalian cells," PLoS One 6, e16270 (2011).

${ }^{2}$ M. H. T. Ngo, J. D. Liao, P. L. Shao, C. C. Weng, and C. Y. Chang, "Increased fibroblast cell proliferation and migration using atmospheric N-2/Ar microplasma for the stimulated release of fibroblast growth factor-7," Plasma Process. Polym. 11, 80-88 (2014).

${ }^{3}$ A. Schmidt, K. Wende, S. Bekeschus, L. Bundscherer, A. Barton, K. Ottmuller, K. D. Weltmann, and K. Masur, "Non-thermal plasma treatment is associated with changes in transcriptome of human epithelial skin cells," Free Radical Res. 47, 577-592 (2013).

${ }^{4}$ H. J. Ahn, K. I. Kim, G. Kim, E. Moon, S. S. Yang, and J. S. Lee, "Atmosphericpressure plasma jet induces apoptosis involving mitochondria via generation of free radicals," PLoS One 6, e28154 (2011).

${ }^{5}$ E. Turrini, R. Laurita, A. Stancampiano, E. Catanzaro, C. Calcabrini, F. Maffei, M. Gherardi, V. Colombo, and C. Fimognari, "Cold atmospheric plasma induces apoptosis and oxidative stress pathway regulation in T-lymphoblastoid leukemia cells," Oxid. Med. Cell, Longevity 2017, 1.

${ }^{6}$ F. Virard, S. Cousty, J. P. Cambus, A. Valentin, P. Kemoun, and F. Clement, "Cold atmospheric plasma induces a predominantly necrotic cell death via the microenvironment," PLoS One 10, e0133120 (2015).

${ }^{7}$ M. Keidar, "Plasma for cancer treatment," Plasma Sources Sci Technol. 24, 033001 (2015).

${ }^{8}$ D. B. Graves, "Low temperature plasma biomedicine: A tutorial review," Phys Plasmas 21, 080901 (2014).

${ }^{9}$ A. Privat-Maldonado, A. Schmidt, A. Lin, K. D. Weltmann, K. Wende, A. Bogaerts, and S. Bekeschus, "ROS from physical plasmas: Redox chemistry for biomedical therapy," Oxid. Med. Cell Longevity 2019, 1.

${ }^{10} \mathrm{~S}$. J. Kim and T. H. Chung, "Cold atmospheric plasma jet-generated RONS and their selective effects on normal and carcinoma cells," Sci. Rep. 6, 20332 (2016).

${ }^{11}$ K. Wende, S. Reuter, T. von Woedtke, K. D. Weltmann, and K. Masur, "Redoxbased assay for assessment of biological impact of plasma treatment," Plasma Process. Polym. 11, 655-663 (2014).

${ }^{12}$ S. N. Zucker, J. Zirnheld, A. Bagati, T. M. DiSanto, B. Des Soye, J. A. Wawrzyniak, K. Etemadi, M. Nikiforov, and R. Berezney, "Preferential induction of apoptotic cell death in melanoma cells as compared with normal 
keratinocytes using a non-thermal plasma torch," Cancer Biol. Ther. 13, 1299-1306 (2012)

${ }^{13}$ J. Tornin, M. Mateu-Sanz, A. Rodriguez, C. Labay, R. Rodriguez, and C. Canal, "Pyruvate plays a main role in the antitumoral selectivity of cold atmospheric plasma in osteosarcoma," Sci. Rep. 9, 1 (2019).

${ }^{14}$ M. Keidar, R. Walk, A. Shashurin, P. Srinivasan, A. Sandler, S. Dasgupta, R. Ravi, R. Guerrero-Preston, and B. Trink, "Cold plasma selectivity and the possibility of a paradigm shift in cancer therapy,” Br. J. Cancer 105, 1295-1301 (2011).

${ }^{15}$ A. Lin, B. Truong, S. Patel, N. Kaushik, E. H. Choi, G. Fridman, A. Fridman, and V. Miller, "Nanosecond-pulsed DBD plasma-generated reactive oxygen species trigger immunogenic cell death in A549 lung carcinoma cells through intracellular oxidative stress," Int. J. Mol. Sci. 18, 966 (2017).

${ }^{16}$ M. Leduc, D. Guay, S. Coulombe, and R. L. Leask, "Effects of non-thermal plasmas on DNA and mammalian cells," Plasma Process. Polym. 7, 899-909 (2010).

${ }^{17}$ K. Ogawa, J. S. Oh, N. Gaur, S. H. Hong, H. Kurita, A. Mizuno, A. Hatta, R. D. Short, M. Ito, and E. J. Szili, "Modulating the concentrations of reactive oxygen and nitrogen species and oxygen in water with helium and argon gas and plasma jets," Jpn. J. Appl. Phys., Part 1 58, SAAB01 (2019).

${ }^{18}$ J. S. Oh, E. J. Szili, K. Ogawa, R. D. Short, M. Ito, H. Furuta, and A. Hatta, "UV-vis spectroscopy study of plasma-activated water: Dependence of the chemical composition on plasma exposure time and treatment distance," Jpn. J. Appl. Phys., Part 1 57, 0102B9 (2018).

${ }^{19}$ J. S. Oh, X. Strudwick, R. D. Short, K. Ogawa, A. Hatta, H. Furuta, N. Gaur, S. H. Hong, A. J. Cowin, H. Fukuhara, K. Inoue, M. Ito, C. Charles, R. W. Boswell, J. W. Bradley, D. B. Graves, and E. J. Szili, "How plasma induced oxidation, oxygenation, and de-oxygenation influences viability of skin cells," Appl. Phys. Lett. 109, 203701 (2016).

${ }^{20}$ E. Stoffels, A. J. M. Roks, and L. E. Deelmm, "Delayed effects of cold atmospheric plasma on vascular cells,” Plasma Process. Polym. 5, 599-605 (2008).

${ }^{21}$ C. Jiang, in Low Temperature Plasma Technology Methods and Applications, edited by P. K. Chu and X. Lu (CRC Press, 2013), Chap. 14, pp. 419-441.

${ }^{22} \mathrm{P}$. Heirman, W. Van Boxem, and A. Bogaerts, "Reactivity and stability of plasma-generated oxygen and nitrogen species in buffered water solution: A computational study," Phys. Chem. Chem. Phys. 21, 12881-12894 (2019).

${ }^{23}$ P. Lukes, E. Dolezalova, I. Sisrova, and M. Clupek, "Aqueous-phase chemistry and bactericidal effects from an air discharge plasma in contact with water: Evidence for the formation of peroxynitrite through a pseudo-second-order post-discharge reaction of $\mathrm{H}_{2} \mathrm{O}_{2}$ and $\mathrm{HNO}_{2}$," Plasma Sources Sci. Technol. 23, 015019 (2014).

${ }^{24}$ C. Q. Jiang and S. T. Song, "Ignition and dynamics of nanosecond pulsed helium streamers over a water electrode," Jpn. J. Appl. Phys., Part 1 56, 046101 (2017).

${ }^{25}$ T. Verreycken, R. Mensink, R. van der Horst, N. Sadeghi, and P. J. Bruggeman, "Absolute $\mathrm{OH}$ density measurements in the effluent of a cold atmosphericpressure $\mathrm{Ar}-\mathrm{H}_{2} \mathrm{O}$ RF plasma jet in air," Plasma Sources Sci. Technol, 22, 055014 (2013).

${ }^{26}$ X. Pei, Y. Lu, S. Wu, Q. Xiong, and X. Lu, "A study on the temporally and spatially resolved $\mathrm{OH}$ radical distribution of a room-temperature atmosphericpressure plasma jet by laser-induced fluorescence imaging," Plasma Sources Sci. Technol. 22, 025023 (2013).
${ }^{27}$ S. Kanazawa, H. Kawano, S. Watanabe, T. Furuki, S. Akamine, R. Ichiki, T. Ohkubo, M. Kocik, and J. Mizeraczyk, "Observation of $\mathrm{OH}$ radicals produced by pulsed discharges on the surface of a liquid," Plasma Sources Sci. Technol. 20, 034010 (2011).

${ }^{28}$ S. T. Song, E. B. Sozer, and C. Q. Jiang, "Effects of pulse width on He plasma jets in contact with water evaluated by $\mathrm{OH}(\mathrm{A}-\mathrm{X})$ emission and $\mathrm{OHaq}$ production,” Jpn. J. Appl. Phys., Part 1 58, 066002 (2019).

${ }^{29}$ M. Saran and K. H. Summer, "Assaying for hydroxyl radicals: Hydroxylated terephthalate is a superior fluorescence marker than hydroxylated benzoate," Free Radical Res. 31, 429-436 (1999).

${ }^{30} \mathrm{R}$. W. Matthews, "The radiation-chemistry of the terephthalate dosimeter," Radiat. Res. 83, 27-41 (1980).

${ }^{31} \mathrm{X}$. W. Fang, G. Mark, and C. vonSonntag, "OH radical formation by ultrasound in aqueous solutions part 1 . The chemistry underlying the terephthalate dosimeter," Ultrason. Sonochem. 3, 57-63 (1996).

${ }^{32}$ G. Krumschnabel, M. Fontana-Ayoub, Z. Sumbalova, J. Heidler, K. Gauper, M. Fasching, and E. Gnaiger, "Simultaneous high-resolution measurement of mitochondrial respiration and hydrogen peroxide production," Methods Mol. Biol. 1264, 245-261 (2015).

${ }^{33}$ S. Guo, D. L. Jackson, N. I. Burcus, Y. J. Chen, S. Xiao, and R. Heller, "Gene electrotransfer enhanced by nanosecond pulsed electric fields," Mol. Ther. Methods Clin. Dev. 1, 14043 (2014).

${ }^{34} \mathrm{P}$. Bruggeman and D. C. Schram, "On OH production in water containing atmospheric pressure plasmas,” Plasma Sources Sci. Technol. 19, 045025 (2010).

${ }^{35}$ Y. Y. Zhao, T. Wang, M. P. Wilson, S. J. MacGregor, I. V. Timoshkin, and Q. C. Ren, "Hydroxyl radicals and hydrogen peroxide formation at nonthermal plasma-water interface," IEEE Trans. Plasma Sci. 44, 2084-2091 (2016).

${ }^{36}$ R. Sander, "Compilation of Henry's law constants (version 4.0) for water as solvent," Atmos. Chem. Phys. 15, 4399-4981 (2015).

${ }^{37}$ S. Yonemori, Y. Nakagawa, R. Ono, and T. Oda, "Measurement of $\mathrm{OH}$ density and air-helium mixture ratio in an atmospheric-pressure helium plasma jet," J. Phys. D 45, 225202 (2012).

${ }^{38}$ C. Jiang, J. Miles, J. Hornef, C. Carter, and S. Adams, "Electron densities and temperatures of an atmospheric-pressure nanosecond pulsed helium plasma jet in air," Plasma Sources Sci. Technol. 28, 085009 (2019).

${ }^{39}$ G. Busco, A. V. Omran, L. Ridou, J. M. Pouvesle, E. Robert, and C. Grillon, "Cold atmospheric plasma-induced acidification of tissue surface: Visualization and quantification using agarose gel models," J. Phys. D 52, 24LT01 (2019).

${ }^{40} \mathrm{M}$. Ristow, "Unraveling the truth about antioxidants: Mitohormesis explains ROS-induced health benefits," Nat. Med. 20, 709-711 (2014).

${ }^{41}$ K. Kim, H. J. Ahn, J. H. Lee, J. H. Kim, S. S. Yang, and J. S. Lee, "Cellular membrane collapse by atmospheric-pressure plasma jet," Appl. Phys. Lett. 104, 013701 (2014).

${ }^{42}$ R. Laurita, F. Alviano, C. Marchionni, P. M. Abruzzo, A. Bolotta, L. Bonsi, V. Colombo, M. Gherardi, A. Liguori, F. Ricci, M. Rossi, A. Stancampiano, P. L. Tazzari, and M. Marini, "A study of the effect on human mesenchymal stem cells of an atmospheric pressure plasma source driven by different voltage waveforms," J. Phys. D 49, 364003 (2016).

${ }^{43}$ R. S. Arnold, J. Shi, E. Murad, A. M. Whalen, C. Q. Sun, R. Polavarapu, S. Parthasarathy, J. A. Petros, and J. D. Lambeth, "Hydrogen peroxide mediates the cell growth and transformation caused by the mitogenic oxidase Nox1," Proc. Natl. Acad. Sci. U. S. A. 98, 5550-5555 (2001). 